\title{
Android Based Learning Media for Dyscalculia Children at Nurul Jadid Islamic Boarding School
}

\author{
Moh. Syadidul Itqan ${ }^{1}$, Mida Rosida 2 , Dini Melinda Ulfatul Azizah ${ }^{3}$
}

1,2,3 Universitas Nurul Jadid, Indonesia
CORRESPONDENCE: $₫$ itqan@unuja.ac.id.

Article Info

Article History

Received : 15-03-2021

Revised : 26-07-2021

Accepted : 25-08-2021

Keywords:

Dyscalculia:

Android;

Mobile Learning;

Learning Media.

\begin{abstract}
A conditions that are different from other Normal Children in terms of mental, physical, and social characteristics called Children with Special Needs. Dyscalculia is a term referring to a wide range of difficulties with mathematics, including weaknesses in understanding the meaning of numbers, and difficulty applying mathematical principles to solve problems. The difference in conditions with other normal children, required a different approach in Teaching and Learning Activities of the other Normal Children. One of these different approaches is to use mobile learning devices as an effective learning media for Children with Special Needs to realize the material presented by the Teacher.

This research was carried out for the 2020/2021 Students at Junior High School of Nurul Jadid, Karang Anyar Paiton Probolinggo. The purpose of this research is to produce an android application to help Children with Special Needs learn. This research method is research and development. The result of this research is that an android application has been produced as an effective learning media for children with special needs.
\end{abstract}

\section{Introduction}

Pendidikan adalah proses pengembangan diri yang dilakukan terus menerus semasa hidup dalam rangka meningkatkan kemampuan, pengetahuan, pemahaman atau keterampilan seseorang. Proses pendidikan tanpa memandang apapun, seperti jenis kelamin, usia, maupun keadaan seseorang. Setiap warga negara berhak untuk mendapatkan pendidikan yang bermutu yang diselenggarakan oleh pemerintah Republik Indonesia. Hal ini dijamin dalam Undang- Undang Dasar 1945 pasal 31 ayat 1 yang menyatakan bahwa setiap warga negara berhak untuk mendapatkan pendidikan (Perdana, 2004). Oleh karena setiap warga negara berhak memperoleh proses pendidikan, maka berlaku pula bagi Anak Berkebutuhan Khusus (ABK). Anak berkebutuhan Khusus (ABK) merupakan anak berkelainan dengan kategori menyimpang atau berbeda secara spesifik dengan keadaan anak normal pada umumnya, sehingga Anak Berkebutuhan Khusus (ABK) membutuhkan penanganan pendidikan secara khusus sehingga dapat mengembangkan potensi dirinya secara optimal.

Penyimpangan dalam diri Anak Berkebutuhan Khusus (ABK) meliputi aspek fisik, mental, sosial, dan atau emosi. Pelayanan pendidikan berbeda bagi Anak Berkebutuhan Khusus (ABK) sangat dibutuhkan untuk mengembangkan kemampuan ABK secara maksimal, hal ini disebabkan karena ABK mengalami kesulitan atau hambatan fungsi intelektual. Salah satu pelayanan pendidikan tersebut ialah menggunakan pendekatan belajar berbasis mobile. Mobile learning merupakan bagian dari media pembelajaran. Media pembelajaran mempunyai peranan penting yang digunakan oleh guru untuk menyampaikan materi 
pembelajaran (Zaus et al, 2018). Kearney menyatakan bahwa mobile learning dijelaskan dengan berbagai cara, namun deskripsi ini semua mempertimbangkan perhubungan antara bekerja dengan perangkat mobile dan terjadinya pembelajaran: proses pembelajaran dimediasi oleh perangkat mobile (Kearney, 2018). Secara umum diketahui bahwa penggunan smartphone lebih banyak untuk bermain game dan media sosial, hal ini menyebabkan belajar siswa terganggu dikarenakan berkurangnya konsentrasi belajar siswa.

Menanggapi hal tersebut diperlukan upaya menjadikan smartphone sebagai media pembelajaran sehingga siswa dapat belajar secara mandiri. Rumusan masalah penelitian ini adalah bagaimana strategi pembelajaran efektif bagi anak berkebutuhan khus di Kecamatan Paiton berbasis mobile learning. Tujuan penelitian ini adalah menghasilkan aplikasi android untuk membantu belajar anak berkebutuhan khusus. Manfaat penelitian ini adalah (1) Bagi Guru, memberikan alternatif pendekatan mengajar bagi Anak Berkebutuhan Khusus (ABK); (2) Bagi Siswa, membantu siswa memperoleh pelayanan pendidikan secara maksimal; (3) Bagi Masyarakat, membantu proses pendampingan belajar bagi masyarakat yang memiliki Anak Berkebutuhan Khusus (ABK).

Anak Berkebutuhan Khusus (ABK) merupakan anak yang mengalami hambatan dalam proses belajar karena perbedaan kondisi fisik maupun intelektual dengan anak normal lainnya. Salah satu kriteria Anak Berkebutuhan Khusus (ABK) adalah anak dengan kondisi lamban belajar atau slow learner. Menurut Direktorat Pembinaan Sekolah Luar Biasa (PSLB), Anak lamban belajar adalah anak yang memiliki potensi intelektual sedikit di bawah anak pada umumnya (Direktorat PSLB, 2009). Sejalan dengan pendapat tersebut, Yuyus menjelaskan bahwa anak berkesulitan belajar adalah gangguan neurologis yang dapat dialami oleh orang dewasa dan anak- anak bukan dari kecacatan, kesulitan ini bersifat biologis yang terutama diakibatkan oleh lambannya kematangan atau tidak efektifnya fungsi bagian otak tertentu dan mereka memerlukan layanan pendidikan khusus (Yuyus, 2005). Jadi, anak lamban belajar adalah anak dengan kondisi kemampuan intelektual di bawah anak rata- rata dan memerlukan layanan pendidikan khusus.

Menurut Maftuhatin, ciri- ciri yang dapat diamati dari anak lamban belajar adalah

1. Rata- rata prestasi belajarnya rendah (kurang dari 6).

2. Menyelesaikan tugas- tugas akademik sering terlambat dibandingkan dengan teman- teman sebayanya.

3. Daya tangkap terhadap pembelajaran lambat.

4. Pernah tidak naik kelas.

Anak lamban belajar membutuhkan pembelajaran khusus, yaitu:

1. Waktu yang lebih lama.

2. Ketelatenan dan kesabaran guru.

3. Memperbanyak latihan daripada hafalan.

4. Menuntut penggunaan media pembelajaran yang variatif.

5. Diperlukan adanya pengajaran remedial. (Maftuhatin, 2014).

Dari pendapat di atas, dapat diperoleh fakta bahwa penanganan anak lamban belajar salah satunya adalah dengan penggunaan media pembelajaran yang variatif. Sesuai dengan fokus penelitian ini adalah mengembangkan strategi pembelajaran berbasis mobile learning bagi anak berkebutuhan khusus tipe slow learner. Anak berkesulitan belajar secara spesifik, terbagi dalam anak berkesulitan membaca; anak berkesulitan menulis; anak berkesulitan berhitung. Dalam penelitian ini lebih spesifik kepada anak berkesulitan belajar dalam hal berhitung. Adapun ciri- ciri anak berkesulitan dalam berhitung adalah:

1. Sulit membedakan notasi operasi aljabar seperti $\times, \div,+,-$, dll. 
2. Sulit menyelesaikan operasi aljabar dasar.

3. Sulit membedakan bentuk angka diantaranya 6 dengan 9, 14 dengan 41, 5 dengan 2, 8 dengan 3, dll.

4. Sulit menjelaskan bangun- bangun geometri.

5. Sulit menyebutkan bilangan secara berulang.

Salah satu tujuan dari penelitian ini adalah membantu siswa dalam mengatasi berbagai kesulitan di atas. Sehingga Anak Berkebutuhan Khusus (ABK) dapat mengurangi jarak perbedaan spesifik dengan anak normal lainnya.

\section{Method}

Metode penelitian yang digunakan dalam penelitian ini adalah metode penelitian kualitatif. Sedangkan jenis penelitian yang digunakan adalah jenis Research and Development (R\&D) karena penelitian ini bertujuan untuk menghasilkan produk android. Menurut Sugiyono penelitian Research and Development $(R \& D)$ adalah suatu metode penelitian yang digunakan untuk menghasilkan produk tertentu, dan menguji kefektifan produk tersebut (Sugiyono, 2010). Dalam penelitian prosedur yang digunakan adalah model pengembangan ADDIE, ialah model pengembangan yang terdiri dari lima tahapan yang terdiri dari Analysis (Analisis), Design (Desain), Development (Pengembangan), Implementation (Implementasi), dan Evaluating (Evaluasi).

Uji validitas dilakukan dua kali yaitu terhadap media pembelajaran dan materi pembelajaran. Uji validitas dilakukan oleh ahli yang berkompeten di dalam bidangnya. Kemudian ahli diminta untuk memberikan penilaian serta saran terhadap aplikasi yang dibuat. Sehingga akan diperoleh jawaban apakah media pembelajaran yang dihasilkan valid atau tidak valid baik dari segi materi ataupun aplikasinya.Teknik analisis data yang digunakan dalam penelitian ini adalah teknik analisis data deskriptif, yaitu dengan menghitung prosentase nilai hasil validasi.

$$
\text { Prosentase }=\frac{\text { skor diperoleh }}{\text { skor maksimum }} \times 100 \%
$$

Tingkat kelayakan produk hasil penelitian ini ditunjukkan dengan prosentase skor. Semakain besar prosentase skor yang didapat oleh hasil analisis data maka semakin baik tingkat kelayakan produk yang dihasilkan. Adapun kriteria pengambilan keputusan dalam validasi media pembelajaran ini diperoleh dari tabel berikut:

\begin{tabular}{ccc}
\multicolumn{3}{c}{ Tabel 1. Kriteria kelayakan Media [13] } \\
\hline No & Prosentase & Keterangan \\
\hline 1 & $80 \%-100 \%$ & Baik/ valid \\
2 & $60 \%-79,99 \%$ & Cukup \\
3 & $50 \%-59,99 \%$ & Kurang \\
4 & $0 \%-49,99 \%$ & Tidak Baik
\end{tabular}

Penelitian ini dilaksanakan dalam waktu 3 Bulan yaitu dari Bulan Januari - Maret. Bulan januari melaksanakan analisis, di bulan februari melaksanakan design dan development, di bulan maret melaksanakan implemention dan evaluating. Adapun tempat penelitian ini dilaksanakan di SMP Nurul Jadid Paiton Kabupaten Probolinggo dan Laboratorium Komputer Universitas Nurul Jadid Paiton Kabupaten Probolinggo Jawa Timur. Pemilihan sekolah tersebut, karena merupakan Sekolah Menengah Pertama yang 
berada di bawah lingkungan Pondok Pesantren Nurul Jadid. Dalam penelitian ini subjek penelitian ini adalah siswa dengan kategori Anak Berkebutuhan Khusus (ABK) Spesifik kesulitan dalam berhitung (Dyscalculia) Kelas VII dan VIII sebanyak 5 siswa.

\section{Result and Discussion}

Penelitian pengembangan ini menghasilkan aplikasi media pembelajaran berbasis android bagi anak diskalkulia di Pondok Pesantren Nurul Jadid. Penelitian ini menggunakan model pengembangan ADDIE, yaitu model pengembangan yang terdiri dari lima tahapan yang terdiri dari Analysis (Analisis), Design (Desain), Development (Pengembangan), Implementation (Implementasi), dan Evaluating (Evaluasi).

Tahapan - tahapan Analysis (Analisis), Design (Desain), Development (Pengembangan), Implementation (Implementasi), dan Evaluating (Evaluasi). dalam penelitian ini dijelaskan sebagai berikut:

\section{1) Analysis}

Pada tahap ini, peneliti melakukan analisis terhadap materi pembelajaran yang akan digunakan dalam media pembelajaran berbasis android yang akan dikembangkan. Analisis materi yang peneliti lakukan ialah dengan mencari materi dari penelitian yang relevan kemudian dikonsultasikan kepada guru di SMP Nurul Jadid Karang Anyar Paiton Kabupaten Probolinggo. Konsultasi ini bertujuan agar materi pembelajaran yang dikembangkan dalam media pembelajaran berbasis android sesuai dengan keadaan siswa di SMP Nurul Jadid Karang Anyar Paiton Kabupaten Probolinggo. Pada tahap ini juga peneliti meminta masukan kepada Guru di SMP Nurul Jadid Karang Anyar Paiton Kabupaten Probolinggo mengenai materi tambahan yang akan dimasukkan dalam media pembelajaran berbasis android.

\section{2) Design}

Tahap selajutnya adalah mendesain rancangan awal yang berkaitan dengan media pembelajaran berbasis android yang akan dikembangkan. Pada tahap ini juga, beberapa fitur ditentukan oleh peneliti untuk dimasukkan pada media pembelajaran. Selain itu, beberapa konten pendukung juga dipilih oleh peneliti untuk media pembelajaran yang akan dikembangkan seperti audio, gambar, video, dll. Dalam tahap design ini peneliti juga menyiapkan lembar validasi tentang materi pembelajaran dan media pembelajaran yang dikembangkan.

\section{3) Development}

Pada tahap pengembangan, rancangan awal yang sudah dibuat pada tahap desain kemudian dikembangkan menggunakan software pengembang android untuk dijadikan aplikasi android. Dalam media pembelajaran berbasis android yang dikembangkan ini memiliki beberapa halaman, diantaranya halaman materi, halaman soal, dan halaman skor akhir. Selain itu fitur yang yang ada dalam media pembelajaran ini dibuat semudah mungkin bagi Anak Berkebutuhan Khusus (ABK) tipe diskalkulia. 


\section{4) Implementation}

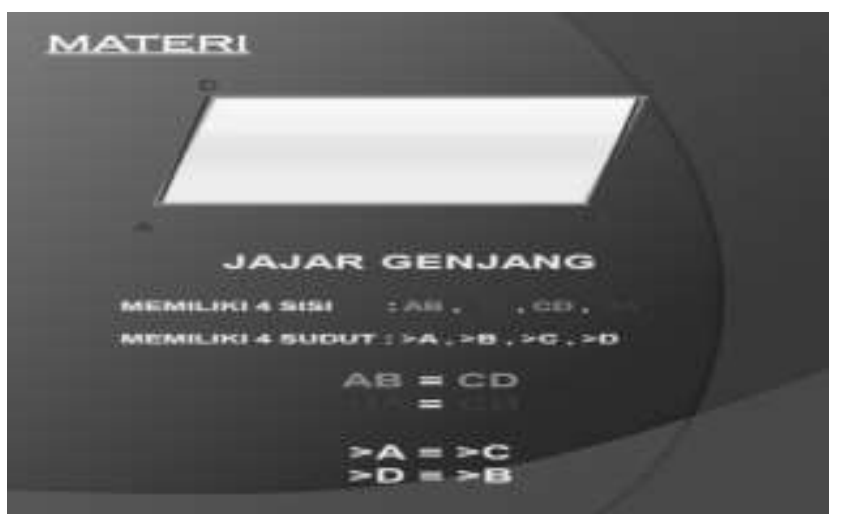

Gambar 1. Contoh Halaman Media Pembelajaran

Pada tahap ini, aplikasi media pembelajaran berbasis android yang sudah dikembangkan, diuji cobakan kepada pengguna aplikasi yaitu guru dan siswa SMP Nurul Jadid Karanganyar Paiton.

\section{5) Evaluating}

Tahap ini merupakan akhir dari beberapa tahapan pengembangan media pembelajaran berbasis android. Pada tahap ini peneliti melakukan evaluasi yang bersumber dari lembar validasi oleh ahli baik materi pembelajaran maupun media pembelajaran berbasis android yang dikembangkan. Jika aplikasi android yang dihasilkan dinyatakan valid, maka penelitian dapat disimpulkan selesai, namun jika dinyatakan belum valid, maka penelitian dimulai dari tahap pertama. Dalam penelitian ini, peneliti menggunakan tiga validator ahli dalam bidang ilmu komputer yaitu Kamil Malik, M.Kom., Wahab Sya'roni, M.Kom., dan Abu Tholib, M.Kom. untuk memvalidasi media pembelajaran berbasis android. Sedangkan validator ahli materi pembelajaran yaitu oleh Guru Kelas VIII SMP Nurul Jadid Karang Anyar Paiton Kabupaten Probolinggo.

Tabel 3. Hasil Validasi Ahli I

\begin{tabular}{ccc}
\hline No & Aspek & Prosentase \\
\hline 1 & Tampilan Aplikasi & 82 \\
2 & Penggunaan Fitur & 80 \\
3 & Petunjuk Penggunaan & 85 \\
4 & Penggunaan Bahasa & 82 \\
\hline & Rata- Rata & 82,25 \\
\hline
\end{tabular}

Tabel 4. Hasil Validasi Ahli II

\begin{tabular}{ccc}
\hline No & Aspek & Prosentase \\
\hline 1 & Tampilan Aplikasi & 85 \\
2 & Penggunaan Fitur & 84 \\
3 & Petunjuk Penggunaan & 82 \\
4 & Penggunaan Bahasa & 83 \\
\hline & Rata- Rata & 83,5 \\
\hline
\end{tabular}

Tabel 5. Hasil Validasi Ahli III

\begin{tabular}{ccc}
\hline No & Aspek & Prosentase \\
\hline 1 & Tampilan Aplikasi & 84 \\
2 & Penggunaan Fitur & 82 \\
3 & Petunjuk Penggunaan & 84 \\
4 & Penggunaan Bahasa & 85 \\
\hline & Rata- Rata & 83,75 \\
\hline
\end{tabular}


Berdasarkan hasil validasi tiga ahli validasi di atas diperoleh data bahwa Validator I memberikan ratarata prosentase media pembelajaran berbasis android sebesar 82,25\% (Baik/ Valid), sedangkan Validator II memberikan rata- rata prosentase media pembelajaran berbasis android sebesar 83,5\% (Baik/ Valid), dan Validator III memberikan rata- rata prosentase media pembelajaran berbasis android sebesar 83,75\% (Baik/ Valid). Sehingga dapat disimpulkan bahwa aplikasi android bagi anak berkebutuhan khusus adalah Baik / Valid. Hal ini menunjukkan bahwa media pembelajaran berbasis android yang dikembangkan memiliki tampilan aplikasi yang menarik, penggunaan fitur yang mudah, penggunaan bahasa yang baik, dan memiliki petunjuk penggunaan yang mudah dipahami.

Sedangkan hasil analisis validasi materi pembelajaran dalam media pembelajaran berbasis android diperoleh sebagai berikut:

\begin{tabular}{ccc}
\multicolumn{3}{c}{ Tabel 6.Hasil Validasi Materi Pembelajaran } \\
\hline No & Aspek & Prosentase \\
\hline 1 & Kesesuaian Materi & 84 \\
2 & Kesesuaian Soal & 82 \\
3 & Ilustrasi Materi & 85 \\
4 & Penggunaan Bahasa & 84 \\
\hline \multicolumn{3}{c}{ Rata- Rata } \\
\hline
\end{tabular}

Berdasarkan hasil validasi materi pembelajaran di atas diperoleh data bahwa rata- rata prosentase materi pembelajaran yang diberikan Validator pada media pembelajaran berbasis android sebesar 83,75\% (Baik/ Valid). Sehingga dapat disimpulkan bahwa materi pembelajaran dalam aplikasi android bagi anak berkebutuhan khusus yang dikembangkan adalah Baik / Valid. Hal ini menunjukkan bahwa media pembelajaran berbasis android yang dikembangkan memiliki materi pembelajaran yang sesuai bagi Anak Berkebutuhan Khusus (ABK) Tipe Diskalkulia, soal yang diberikan sesuai bagi Anak Berkebutuhan Khusus (ABK) Tipe Diskalkulia, Ilustrasi materi yang baik untuk membantu pemahaman materi yang diberikan bagi Anak Berkebutuhan Khusus (ABK) Tipe Diskalkulia, dan penggunaan bahasa yang mudah dipahami bagi Anak Berkebutuhan Khusus (ABK) Tipe Diskalkulia. Berdasarkan hasil validasi materi pembelajaran dan media pembelajaran, dapat disimpulkan bahwa media pembelajaran berbasis android ini dinyatakan dapat digunakan bagi Anak Berkebutuhan Khusus.

\section{Conclusion}

Dari hasil penelitian yang telah dilaksanakan dapat disimpulkan bahwa telah dihasilkan media pembelajaran berbasis android bagi Anak Berkebutuhan Khusus tipe diskalkulia di Kecamatan Paiton. Selain itu, aplikasi media pembelajaran berbasis android berdasarkan hasil validasi materi pembelajaran dan media pembelajaran dinyatakan valid, sehingga media pembelajaran berbasis android sudah dapat digunakan bagi Anak Berkebutuhan Khusus (ABK) tipe diskalklulia.

Penulis ingin mengucapkan terima kasih yang sebesar-besarnya kepada semua pihak yang telah membantu dalam penelitian ini, terutama keluarga penulis. Penelitian ini tidak hanya merupakan hasil karya ilmiah seorang penulis tetapi juga kontribusi dari berbagai pihak terkait terutama pembimbing penulis yang 
telah sabar membimbing penulis dalam menyelesaikan penelitian ini, Yayasan Nurul Jadid dan SMP Nurul Jadid dengan para mahasiswa yang sangat terbuka dalam memberikan izin kepada penulis dalam pengambilan data dan telah bersedia meluangkan waktu serta membantu penulis dalam segala kebutuhan di lapangan. Penulis mengucapkan terima kasih kepada semua pihak yang telah banyak membantu yang tidak dapat penulis ungkapkan satu persatu.

\section{References}

Perdana, H. (2004). Amandemen UUD 1945. Surabaya: Departemen Hukum Tata Negara Fakultas Hukum Universitas Airlangga, t.th.

Zaus, M. A., Wulansari, R.E., Islami, S., Pernanda, D. (2018). Perancangan Media Pembelajaran Listrik Statis dan Dinamis Berbasis Android. Journal of Information Technology and Computer Science (INTECOMS) Vol: 1 No.:1.

Kearney, M. Et. Al. (2018). Viewing Mobile Learning from a Pedagogical Perspective. Journal of Research Learning and Technology, 20:1-17.

Direktorat PSLB. (2009). Pedoman Khusus Penyelenggaraan Pendidikan Inklusif. Jakarta Direktorat Jenderal Manajemen Pendidikan Dasar dan Menengah Departemen Pendidikan Nasional.

Yuyus. (2005). Adaptasi Pembelajaran Siswa Berkesulitan Belajar. Bandung: Rizqi.

Sugiyono. (2010). Metode Penelitian Pendidikan. Bandung: Alfabeta. 